\title{
REKAYASA ULANG PROSES BISNIS PADA DEPARTEMEN \\ PENJUALAN, LOGISTIK, DAN AKUNTING \\ (STUDI KASUS: PT GRAMA BAZITA)
}

\author{
Ainun Mochyidin ${ }^{1}$ \\ BINUS Business School \\ Meliana Dewi Hartanto ${ }^{2}$ \\ BINUS Business School \\ Rian Devara ${ }^{3}$ \\ BINUS Business School \\ Marcellus Rantetana ${ }^{4}$ \\ BINUS Business School
}

\begin{abstract}
The continued development of the business world today requires companies to have an 'edge' to compete with other companies. Any characteristic of the company that gives them an opportunity for growth should be put to good use. The use of information technology should support its operating costs and even increase the efficiency and effectiveness of the company. However, the use of this information technology must be balanced with the readiness of existing resources to operate. Without the support of resources, especially human resources available, the use of this technology would be something that is useless. This thesis aims to assist PT. Grama Bazita in improving the efficiency of existing processes that will ultimately reduce the cost and time. The methodology used in the writing of this thesis is an analytical method which consists of a survey of running processes, analysis of the survey findings, and the identification of the needs of information technology as well as designing a new process which should prove more efficient than the prior business processes. From the analysis, it can be concluded that information technology is
\end{abstract}

1, 2, 3 Alumni of BINUS Business School (a_mochyidin@yahoo.com)

4 Faculty of BINUS Business School 
one of the factors driving reengineering, as well as the business needs to improve competitiveness.

Keywords: information technology, data flow, business processes, reengineering.

\begin{abstract}
ABSTRAK
Semakin berkembangnya dunia usaha saat ini serta semakin ketatnya persaingan menjadikan perusahaan harus memiliki keunggulan untuk bersaing dengan perusahaan lainnya. Kesempatan yang ada benarbenar harus dimanfaatkan dengan baik. Penggunaan teknologi informasi dapat menunjang kegiatan operasional perusahaan bahkan meningkatkan efisiensi dan efektifitas dari perusahaan. Namun, penggunaan teknologi informasi ini harus diimbangi dengan kesiapan sumber daya yang ada untuk mengoperasikannya. Tanpa dukungan dari sumber daya, terutama sumber daya manusia yang ada, penggunaan teknologi informasi ini akan menjadi sesuatu yang siasia. Thesis ini bertujuan untuk membantu PT. Grama Bazita dalam meningkatkan efisiensi dari proses-proses yang ada sehingga pada akhirnya akan mengurangi biaya dan waktu. Metodologi yang digunakan dalam penulisan thesis ini adalah metode analisis yang terdiri dari survey atas proses yang berjalan, analisis terhadap temuan survey, identifikasi kebutuhan teknologi informasi serta merancang proses baru yang sekiranya lebih baik dari proses bisnis yang lama. Dari hasil analisis penulis, dapat diambil kesimpulan bahwa teknologi informasi merupakan salah satu faktor pendorong dilakukannya rekayasa ulang, selain karena kebutuhan bisnis untuk meningkatkan daya saing.
\end{abstract}

Kata kunci: teknologi informasi, aliran data, proses bisnis, rekayasa ulang.

\title{
PENDAHULUAN
}

Dewasa ini untuk bisa bertahan dalam persaingan dunia usaha, perusahaan membutuhkan efiensi dan melakukan inovasi-inovasi untuk mempertahankan pangsa pasar yang sudah ada maupun untuk merebut pangsa pasar baru. Keadaan di negara ini yang makin tidak kondusif, kekerasan semakin meningkat, suhu politik yang memanas membuat iklim 
perekonomian negeri ini menjadi tidak menentu. Untuk itu, perusahaan harus melakukan efisiensi di segala bidang agar dapat menekan biaya untuk dapat meningkatkan daya saing.

Perkembangan teknologi dan komunikasi telah memungkinkan perusahaan untuk dapat mengevaluasi mekanisme koordinasi baik di dalam maupun di luar perusahaan. Saat ini, perusahaan tidak dapat lagi bekerja secara tradisional. Dengan penggunaan teknologi yang tepat dapat mengurangi beban pekerjaan yang tidak diperlukan sehingga jumlah karyawan pun dapat dikurangi. Selain itu, karyawan pun pada akhirnya akan tidak akan terbebani dengan pekerjaan yang berlebihan.

Selain pengadaan dan penjualan barang, perusahaan trading juga didukung oleh administrasi and support dari bagian lain. Proses ini melibatkan finance, accounting, logistik, sales, human resource dan information system. Berbagai departemen ini harus saling bekerja sama untuk dapat menghasilkan suatu bisnis proses yang efisien.

Bisnis proses yang sekarang berjalan pada PT. Grama Bazita adalah bisnis proses yang kurang efisien karena masih berjalan secara manual, membutuhkan berbagai birokrasi yang lebih rumit sehingga menyebabkan bisnis proses tidak efisien. Dengan menulis thesis ini, penulis berharap untuk dapat membantu PT. Grama Bazita menganalisa dan membantu memperbaiki proses bisnis yang ada sehingga dapat meningkatkan daya saing perusahaan. Walaupun secara global, penulis sadar bahwa thesis ini merupakan kontribusi kecil dari seluruh persoalan makro yang ada di dalam perusahaan.

Berkantor di Gedung Multika di Jl. Mampang Prapatan Raya kav 7376, Jakarta Selatan, PT Grama Bazita merupakan perusahaan trading yang bergerak di bidang engineering, procuring, konstruksi, dan melayani kebutuhan akan proses industri di Indonesia. PT Grama Bazita berdiri sejak tahun 1986. Kepemilikan sahamnya terbagi mejadi 2 pemilik yaitu 67\% dimiliki oleh PT Pratama Energi Konstruksi Teknologi Indonesia dan sisanya 33\% dimiliki oleh Bpk. M.S. Mennon. PT Grama Bazita memiliki motto perusahaan yaitu "Provide responsive engineering that meets and axceeds user expectations through the use of state-of-the-art engineering and man machine interface technologies". Mewakili beberapa produsen peralatan yang memiliki reputasi yang baik, PT Grama Bazita membangun kekuatan ini dengan mengembangkan dan menyediakan 
jasa layanan engineering secara lengkap. Dengan pelatihan memadai untuk user, konsultan engineering dengan aplikasi dan pengetahuan engineering yang detail dan lengkap, PT Grama Bazita memiliki berbagai klien dari beberapa jenis industri yang berbeda seperti pulp and paper, chemical, petrochemical, viscose, iron and steel, animal feeds, dan edible oils. PT Grama Bazita berdedikasi untuk menyediakan layanan yang berkualitas tinggi and fleksibel untuk mengakomodasi keperluan khusus dari masing-masing kliennya supaya dapat membangun hubungan jangka panjang yang baik.

Staf yang kompeten dan memiliki pengetahuan yang detail adalah sebagai fondasi untuk menyediakan pelayanan yang memuaskan bagi kliennya. Dengan staf teknik yang berpengalaman pada produk dan segala aplikasinya akan dapat menyediakan solusi yang efektif bagi user. Masalah proses dan aplikasi didiskusikan bersama untuk menentukan solusi yang terbaik. PT Grama Bazita mewakili produsen peralatan yang terkenal. Produk yang dipasarkan dikenal sebagai penguasa pangsa pasar dan dipakai oleh banyak perusahaan diseluruh dunia. Ini memberikan kepercayaan kepada user bahwa mereka memakai produk yang bagus dengan layanan yang baik untuk mendukung mereka. Dari proses yang kecil sampai besar termasuk proses yang rumit, PT Grama Bazita sudah berhasil menyelesaikan begitu banyak proyek. PT Grama Bazita telah memiliki pengalaman untuk menyelesaikan banyak proyek sebagi kontraktor utama atau sebagai sub-kontraktor, dengan berbasis EP atau EPC dan memiliki tanggung jawab untuk menyusun jadwal, budget, dan tindakantindakan teknis.

\section{RUMUSAN PERMASALAHAN}

Permasalahan yang terjadi di PT. Grama Bazita terjadi lebih karena adanya proses bisnis yang kurang efektif. Secara singkat, masalahmasalah yang terjadi dapat dirumuskan seperti dibawah ini:

1. Sebenarnya seberapa besar waktu yang terbuang sia-sia karena proses bisnis yang tidak efisien ini ?

2. Dimana letak proses yang tidak efisien?

3. Bagaimana cara memperbaiki proses yang tidak efisien tersebut? 


\section{LANDASAN TEORI}

Business Process Reengineering atau proses rekayasa ulang sangat diperlukan oleh suatu perusahaan dalam mencapai efektifitas dan efisiensi suatu perusahaan. Menurut Hammer dan Champy (1993, p32) rekayasa ulang adalah pemikiran fundamental dan perancangan ulang secara radikal atas proses-proses bisnis untuk mendapatkan perbaikan secara dramatis dalam tolak ukur performance seperti biaya, kualitas, pelayanan, dan kecepatan. Ada beberapa kata kunci yang memegang peranan penting dari deifinisi rekayasa ulang di atas yaitu : fundamental, radikal, dramatis, dan kata proses itu sendiri. Fundamental bermakna adalah dengan mengajukan pertanyaanpertanyaan yang paling mendasar yang berkaitan dengan perusahaan dan bagimana cara mengoperasikannya. Radikal bermakna bahwa dalam merancang ulang dimulai dari akar permasalahan. Arti kata dramatis bermakna bahwa Rekayasa ulang bukanlah tentang upaya mencapai peningkatan secara inkremental, tetapi tentang pencapaian suatu lompatan besar (quantum leaps) dalam hal kinerja perusahaan secara dramatis. Dan yang paling terakhir adalah proses yang mempunyai makna sekumpulan aktivitas yang memerlukan satu atau beberapa jenis masukan (input) dan menghasilkan keluaran (output) yang mempunyai nilai bagi customer.

Dalam suatu proses rekayasa ulang, terkadang pemanfaatan teknologi informasi dapat memberikan peranan yang sangat penting. Teknologi informasi sendiri mencakup komponen teknologi yang dibutuhkan untuk mengolah, menyimpan dan menyampaikan informasi (Luhukay, 1994). Davenport dan Short (1990) beragumentasi bahwa BPR membutuhkan pandangan yang luas antara IT dengan aktivitas bisnis, dan hubungan antara keduanya. IT harus dilihat lebih dari sekedar otomatisasi atau kekuatan mesin: untuk secara fundamental mempertajam cara bisnis dilakukan. Kapasitas IT harus mendukung proses bisnis, dan bisnis proses harus berada dalam kapasitas yang dapat diberikan oleh IT.

Kemajuan teknologi informasi yang pesat telah menjadikan teknologi informasi sebagai salah satu komponen utama dalam format perusahaan baru sebagai hasil BPR (Richardus Eko Indrajit, 2000). Perkembangan teknologi informasi seperti local area network, wide area network, multimedia, data warehouse, intranet, dan internet telah 
membuat perusahaan mendefinisikan kembali visi dan misi bisnisnya, terutama yang berkaitan dengan strategi pelaksanaan bisnis. Ada empat cara improvisasi yang dapat dilakukan terhadap proses-proses dalam perusahaan yang ditawarkan oleh teknologi informasi (Peppard, 1995) yaitu: Eliminate, Simplified, Integrate, Automate.

Faktor-faktor yang mendukung dilaksanakannya proses rekayasa ulang di bisnis menurut Grant Thornton (1994) adalah: Reduced cost (84\%), Improve Quality $\quad$ (79\%), Increase speed (throughput) (62\%), Overcome a competitive threat (50\%), Change the organization structure (35\%), Others (9\%). Menurut Johansson, McHugh, Pendlebury dan Wheeler (1995, p58) suatu ukuran kinerja yang menjadi tujuan utama dari reka ulang dapat berupa: Pengurangan waktu siklus, Pengurangan biaya dan peningkatan laba, Meningkatkan efisiensi melalui peningkatan produktivitas dan beban kerja dari sumber daya.

Untuk mencapai tujuan utama dari reka ulang maka perlu melakukan perubahan terhadap proses yang ada dengan cara: menghilangkan bagian proses yang tidak penting, menerapkan teknologi pada bagian yang memungkinkan, pemberdayaan dengan mengalihkan tanggung jawab pengambilan keputusan dan kontrol kepada level dimana pekerjaan dilakukan, memperbaiki alur kerja dengan penekanan pada fungsi yang memberikan nilai tambah, dan menetapkan kriteria pengukuran yang berguna untuk analisis dan pembuatan rencana strategis.

Menurut Davenport (1993), tahapan-tahapan yang akan dilakukan dalam rekayasa ulang proses bisnis adalah: ${ }^{1 .}$ Membuat visi bisnis dan menetapkan tujuan, mencakup prioritas dari obyektif dan mengevaluasi kemampuan dari perusahaan dalam melakukan suatu perubahan, ${ }^{2}$ Memahami proses yang ada yaitu dengan membuat suatu model dan mengukurnya untuk dijadikan sebagai basis dan mengetahui letak terjadinya permasalahan., ${ }^{3 .}$ Mengindentifikasikan proses yang akan dirubah, dengan fokus pada critical success factors yang paling memungkinkan untuk dirubah., ${ }^{4}$ Mencari peluang pemakaian teknologi informasi pada bagian-bagian yang sesuai. Penentuan dimana teknologi informasi dapat diterapkan pada proses bisnis yang ada serta kemampuan departemen teknologi informasi didalam perusahaan untuk terlibat secara aktif di dalam proses 
rekayasa., ${ }^{5}$ Membuat model/prototype dari proses baru yang lebih ramping, efisien dan efektif serta mensimulasikannya untuk memperkirakan kinerja kerjanya.

Rekayasa ulang memiliki fokus pada inovasi, kecepatan, pelayanan dan kualitas. Rekayasa ulang menyediakan proses yang super efisien yang membawa pada peningkatan yang radikal. Lima tahap dalam melakukan rekayasa ulang menurut Victor S.L. Tan (1994, p37-41) adalah: ${ }^{1}$ Memahami proses yang sedang berlangsung, ${ }^{2}$ Mencari titik lemah proses saat ini, ${ }^{3}$ Menyelidiki alternatif rancangan ulang, ${ }^{4}$ Mencari informasi yang diperlukan untuk mendukung proses rekayasa ulang.. ${ }^{5}$ Melakukan tes kelayakan terhadap rancangan proses yang baru.

\section{METODOLOGI PERANCANGAN}

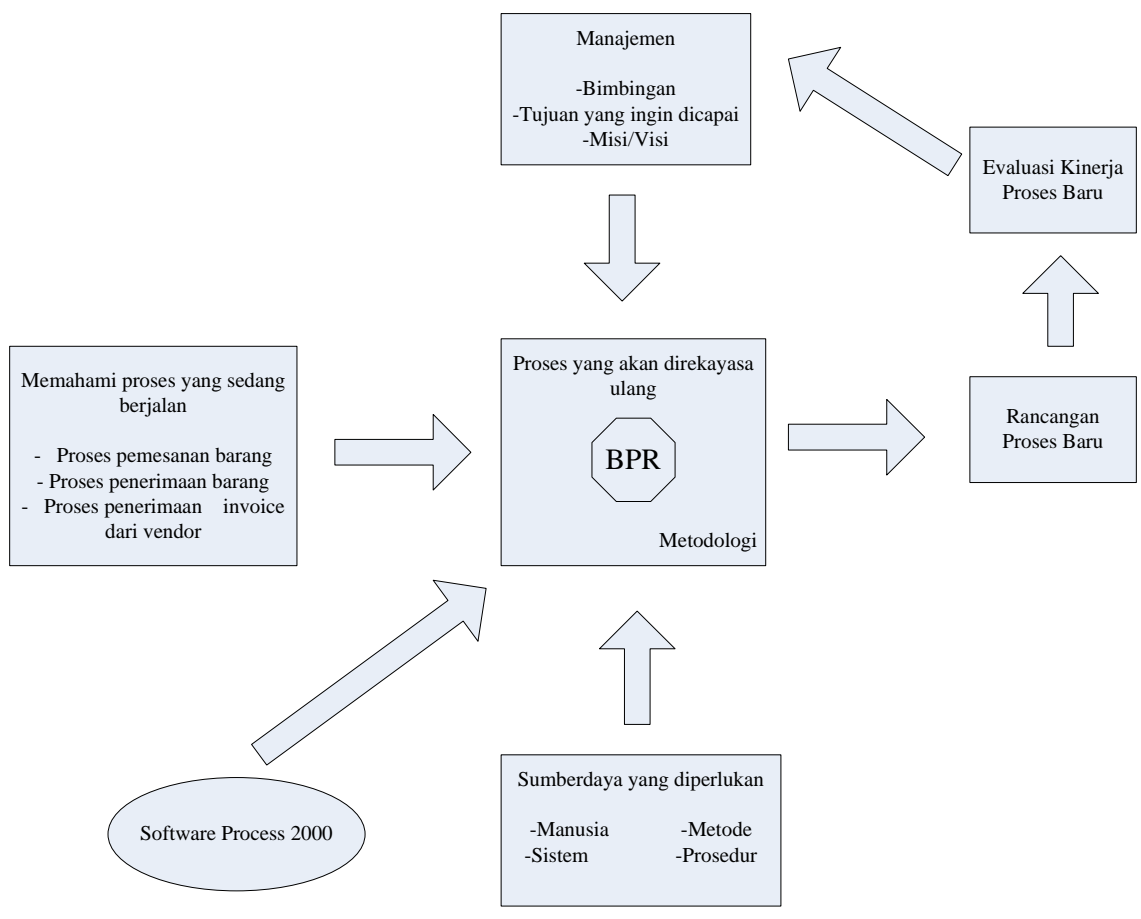

Gambar 1. Kerangka Pikir Rekayasa Ulang Pada PT Grama Bazita 
Pada mulanya proses yang sekarang berjalan di PT Grama Bazita dipahami terlebih dahulu. Proses yang dimaksud disini dibatasi hanya pada proses pemesanan barang yang dilakukan oleh departemen sales dan logistik, proses penerimaan barang dan pengecekan dengan outgoing purchase order yang dilakukan oleh departmen logistik, serta proses penerimaan invoice dari vendor yang ditangani oleh departemen accounting.

Setelah memahami proses yang berjalan, selanjutnya penulis akan menganalisa proses mana saja yang sekiranya perlu untuk direkayasa ulang dengan menggunakan bantuan perangkat lunak Process 2000. Dalam proses rekayasa ulang ini, manajemen akan memberikan bimbingan serta mengarahkan rekayasa ulang ini agar tetap sesuai dengan visi/misi perusahaan serta sejalan dengan tujuan yang ingin dicapai oleh perusahaan. Selain memberikan bimbingan, manajemen juga menyediakan sumber daya yang dibutuhkan dalam proses rekayasa ulang ini.

Dengan mengetahui kekurangan dari proses yang sedang berjalan, penulis dapat memberikan usulan proses baru yang dapat memperbaiki kekurangan dari proses yang lama, meningkatkan efisiensi serta efektifitas dari perusahaan.

Setelah dibuatnya rancangan proses baru, selanjutnya penulis mengevaluasi kinerja proses yang diusulkan ini. Apakah kinerja usulan proses baru ini dapat lebih baik dari proses yang lama serta dapat memperbaiki kekurangan-kekurangan yang ada dalam departemen terkait (Sales, Logistik, Accounting dan Finance). Usulan proses baru ini juga diukur efisiensinya dengan menggunakan perangkat lunak Process 2000.

\section{HASIL}

Dengan menggunakan process2000, dapat dilihat hasil perbandingan antara proses bisnis yang lama dengan proses bisnis yang baru. Adapun perbandingan hasil yang diperoleh dapat dilihat pada tabel dibawah ini : 
Tabel 1. Perbandingan Proses Bisnis

\begin{tabular}{|c|c|c|c|c|c|c|}
\hline & \multicolumn{3}{|c|}{ Proses Bisnis Lama } & \multicolumn{3}{|c|}{ Proses Bisnis Baru } \\
\hline & $\begin{array}{c}\text { Waktu } \\
\text { rata- } \\
\text { rata }\end{array}$ & $\begin{array}{l}\text { Resources } \\
\text { Cost }\end{array}$ & SDM & $\begin{array}{c}\text { Waktu } \\
\text { rata- } \\
\text { rata }\end{array}$ & $\begin{array}{l}\text { Resources } \\
\text { Cost }\end{array}$ & SDM \\
\hline Proses & & & & & & \\
\hline Pemesanan & 57615 & & 12 & 46280 & & 12 \\
\hline Barang & menit & $\$ 301,858.17$ & orang & menit & $\$ 108,874.52$ & orang \\
\hline Proses & & & & & & \\
\hline Penerimaan & 4365 & & 14 & 1560 & & 14 \\
\hline Barang & menit & $\$ 43,533.16$ & orang & menit & $\$ 14,430.40$ & orang \\
\hline Proses & & & & & & \\
\hline Penerimaan & 4320 & & 3 & 1475 & & 3 \\
\hline Invoice & menit & $\$ 97,539.75$ & orang & menit & $\$ 20,897.02$ & orang \\
\hline
\end{tabular}

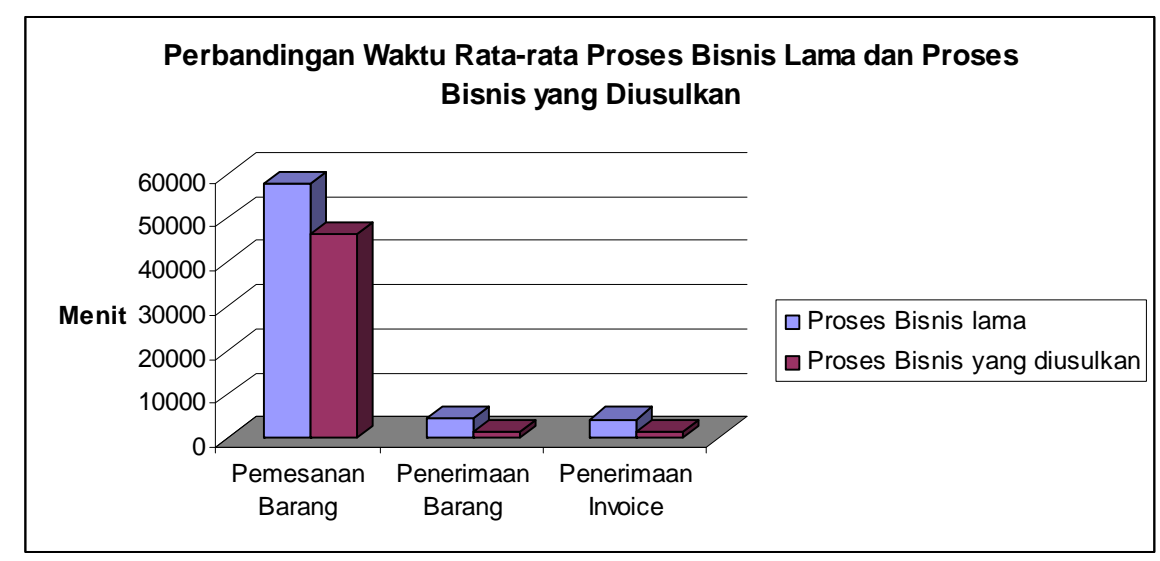

Grafik 1. Perbandingan Waktu Rata-Rata Proses Bisnis

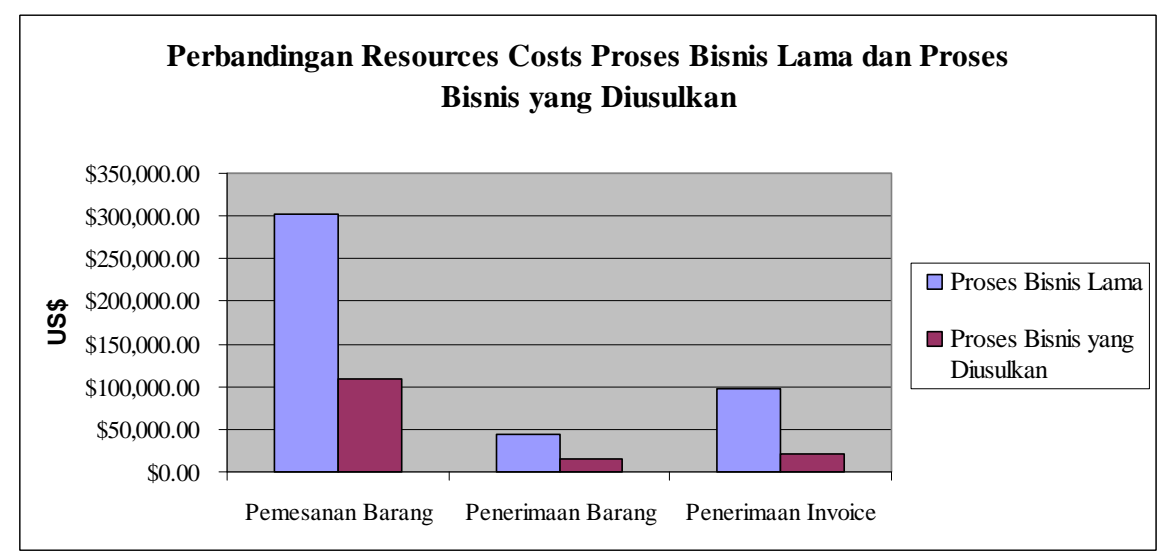

Grafik 2. Perbandigan Resources Costs Proses Bisnis 
Dari tabel dan gambar diatas dapat digambarkan bahwa proses bisnis yang diusulkan memberikan penghematan waktu yang signifikan. Sementara untuk penggunaan SDM, proses bisnis yang diusulkan menggunakan SDM sebanyak proses bisnis lama, namun proses pemesanan barang, pada kegiatan persetujuan incoming PO oleh manajemen yang biasanya dilakukan oleh 3 orang, dalam proses bisnis yang diusulkan, kegiatan ini hanya dilakukan oleh 2 orang saja. Pada proses bisnis yang diusulkan hampir seluruh kegiatan dalam proses-proses yang ada sudah terkomputerisasi, dan aliran data dapat dilakukan secara elektronik.

Sementara itu, untuk perbandingan resources costs antara proses bisnis lama dan proses bisnis yang diusulkan terdapat perbedaan biaya yang cukup signifikan. Dalam hal ini, penulis menggunakan mata uang US\$ untuk pengukuran resources costs dan menggunakan asumsi bahwa 1 US\$ senilai dengan Rp. 10.000. Pada proses penerimaan barang, dapat dilihat bahwa resource cost untuk proses yang diusulkan lebih besar daripada proses lama karena penggunaan komputer yang semakin sering, sedangkan cost untuk worker lebih berkurang, jadi dapat disimpulkan bahwa pada proses-proses yang diusulkan ini, pemakaian resource berupa komputer lebih meningkat dan penggunaan resource berupa worker penggunaannya menurun secara drastis.

\section{KESIMPULAN}

Kesimpulan dapat diperoleh dari hasil analisis dan perancangan pada bab sebelumnya, diantaranya adalah sebagai berikut:

1. Proses yang tidak diperlukan seperti penduplikasian persetujuan sebaiknya dihilangkan untuk lebih menyederhanakan proses dan demi tercapainya efisiensi

2. Dengan menggunakan bantuan teknologi informasi, persetujuan dokumen-dokumen secara pertukaran data dapat dilakukan secara elektronik sehingga dapat dicapai pengurangan waktu antara $19,67 \%$ sampai $65,85 \%$ pada tiap proses

3. Dengan digunakannya aliran data secara elektronik akan mempengaruhi tugas dan tanggung jawab bagian yang terkait dan memerlukan keahlian dibidangnya 
4. Teknologi informasi merupakan salah satu faktor pendorong dilakukannya rekayasa ulang selain karena kebutuhan bisnis untuk meningkatkan daya saing

\section{DAFTAR ACUAN}

Champy, James, 1995, Rekayasa Ulang Perusahaan : Sebuah Manifesto Bagi Revolusi Bisnis, PT. Gramedia Pustaka Utama, Jakarta.

Davenport, Thomas H, 1993, Process Innovation, Reengineering Work Through Information Technology, Harvard Business School Press.

Harrington, H.James, Business Process Improvement, Mc Graw-Hill Inc, 1991

Manganelli, Raymond L. and Mark M. Klein, 1994, The Reengineering Handbook, Amazon, New York.

Tan, Victor S.L., 1994, Change to Win, Times Books International, Singapore.

\section{DAFTAR PUSTAKA}

Indrajit, Richardus Eko, 2000, Manajemen Sistem Informasi dan Teknologi Informasi, PT. Elex Media Komputindo, Jakarta.

Irawan, Oscar Bambang, Rekayasa Ulang Proses Pengadaan Barang, Thesis, Program Pasca Sarjana, Universitas Bina Nusantara Jakarta, 2001.

Johanson, H.J., McHugh P.,Pendlebury, A.J., \& Wheeler III, W.A., 1995, Rekayasa Ulang Proses Bisnis, Binarupa Aksara, Jakarta. 
Laguna, Manuel and Johan Marklund, 2005, Business Process Modelling, Simulation, and Design, Prentice Hall, New Jersey.

Lowenthal, J.N, 1996, Reengineering The Organization: A Step by Step Approach to Corporate Revitalization, Toppan Company (S) Pte Ltd., Singapore.

Luhukay, Joseph, 1994, “Teknologi Informasi : Sebuah Taksonomi yang Lebih Holistik" Advanced Technology Introduction Rev.1.0 , Bina Nusantara, Jakarta.

Peppard, Joe and Phillip Rowland, 1995, The Essence of Business Process Reengineering, Prentice Hall , United Kingdom.

50) Mochyidin, Ainun, et al / Journal of Applied Finance and Accounting 4(1) 39-50 